УДК 811.161.2'23'38:316

DOI https://doi.org/10.52726/as.humanities/2021.3.13

\author{
Г. М. ТРУБА \\ кандидат філологічних наук, дочент, \\ домент кафедри прикладної лінгвістики, \\ Одеський національний університет імені I. І. Мечникова, м. Одеса, Украӥна \\ Електронна пошта: 3182009060@ukr.net \\ http://orcid.org/0000-0001-9944-0476
}

\title{
ОСВІТЯНСЬКИЙ ДИСКУРС: ОСНОВНІ ПОНЯТТЯ І ДИФЕРЕНЦЙНІ ОЗНАКИ
}

Актуальність теми, а саме розмежування наукового (освітнього) і освітянського дискурсу, полягає у популяризації освітніх програм і освіти, що спричинило випрацювання нових освітянських традицій. Мета статті окреслити межі нового дискурсу - освітянського. Об'єкт дослідження - різні рівні функціонування української мови, а предмет - чітке окреслення теоретичних і практичних засад синтезу класичних підходів в освітянському дискурсі з сучасними розробками в ділянці нейролінгвістики, сугестології, нейролінгвістичного програмування і сучасних технічних засобів (телефон, комп'ютер) і мережі «Інтернет» у процесі навчання. На відміну від наукового дискурсу в межах лінгвоперсонологічної спрямованості нашого дослідження, визначаємо як особливий тип інституційного спілкування соціокультурний та когнітивно-комунікативний феномен, у центрі якого перебуває дискурсивна діяльність представників наукової громадськості, що забезпечує втілення їхніх інтенцій і досягнення перлокутивного ефекту з метою передачі фахових знань та для інтелектуального й емоційного впливу на адресанта / адресантів. Виокремлено такі ознаки освітянського дискурсу в зіставленні з науковим, як статусно некваліфіковані учасники (у науковому дискурсі - статусно кваліфіковані учасники), нелокалізований хронотоп (у науковому дискурсі - чітко локалізований хронотоп), визначена в межах певного соціального інституту мета (спільне 3 науковим дискурсом), ритуально зафіксовані цінності (ці цінності відчутно різняться із науковим дискурсом), інтенційно закріплені стратегії (ці стратегії питомо різняться із класичним науковим дискурсом і продиктовані форматом нових платформ освіти), необмежена номенклатура жанрів (під впливом сучасних освітніх платформ формуються нові жанри чи форматуються старі), зумовлений арсенал прецедентних феноменів (цей арсенал відчутно різниться із класичними).

Ключові слова: дискурс, освітній дискурс, освітянський дискурс.

Постановка проблеми Коріння вивчення наукового дискурсу як складника загальної культури сягає класичних трактатів Демокрита, Аристотеля, Р. Декарта, І. Ньютона, І. Канта та інших. Сьогодні серед учених, які розробляють цю проблему, варто назвати таких авторів, як О. Галицька, М. Глушко, Г. Дедюра, К. Жук, Н. Зелінська, О. Ільченко, І. Лівіцька, В. Карасик, І. Колегаєва, І. Колесникова, С. Мойсеєнко, Т. Монахова, О. Морозова, А. Нікітіна, Н. Разінкіна, А. Романченко, О. Петровська, І. Скрипак, С. Соколовська, С. Шепітько, І. Фролова.

Загалом освіта в Україні перебуває в умовах гуманізації, гуманітаризації та стрімкого розвитку полікультурного суспільства, що сприяло переосмисленню культурно-ціннісних орієнтирів, що своєю чергою значно актуалізує потребу в підготовці фахівців, здатних до кроскультурної комунікації та педагогічного спілкування засобами іноземної мови в інноваційно-технологічному просторі, здійснення ефективної професійно-педагогічної діяльності.
Основним джерелом відомостей про державну політику у сфері національної мовної політики, інформації про зміни в системі мови і про культурні особливості країни виучуваної мови виступає викладач. 3 цього погляду, науковий і освітянський дискурс (як частина наукового) перебувають в авангарді змін. А проблема підготовки відповідних фахівців із навичками фасилітативної діяльності стає наріжною. Це зумовлює пошук нових освітніх парадигм і концепцій, принципів та підходів до організації освітнього процесу, а також методів, форм i засобів навчання студентів, упровадження технологічних інновацій, які сприятимуть підвищенню якості іншомовної філологічної освіти. Впровадження до навчання студентів різних спеціальностей технологічних інновацій сприятиме формуванню базових компетентностей, готовності до застосування технологічних інновацій у майбутній професійно-педагогічній діяльності, розвитку універсальних соціальних навичок ("soft skills") європейського рівня. 
У цьому контексті магістральні напрями реформування вищої освіти в окреслені в таких нормативно-правових документах: 2002 р. Закон України «Про інноваційну діяльність», 2003 р. - Закон України «Про пріоритетні напрями інноваційної діяльності в Україні», 2003 р. - нормативно-правові акти ЮНЕСКО, Загальноєвропейські рекомендації 3 мовної освіти, ратифіковані на території України, 2012 р. - Закон України «Про засади державної мовної політики», 2014 р. - Закон України «Про вищу освіту», 2017 р. - Закон України «Про освіту», 2009 р. - Програмний документ «Біла книга національної освіти України», 2011 р. Концепція мовної освіти, 2011 р. - Національна рамка кваліфікації, 2016 р. - Концепції реалізації державної політики у сфері реформування загальної середньої освіти «Нова українська школа», 2019 р. - Закон України «Про мову».

Аналіз останніх досліджень і публікацій. Детальний аналіз наявних підходів до поняття дискурс подано в роботах Бацевича, Бисималиева, Макарова, Морозової, Карасика, Кравченка, Сахарової, Чернявскої, Сушко-Безденежних, Brown. Питання, пов'язані з науковим і освітянським дискурсом, стали предметом вивчення дослідників, які працюють у різних галузях гуманітарного знання - філософії (Е. Паніткова), психології (Л. Засєкіна, О. Лавриненко, О. Леонтьєв, Г. Мерфі, Т. Слотіна, О. Уланович), соціології (Є. Боринштейн) тощо. У межах лінгвістичної парадигми цією проблематикою опікуються вітчизняні та зарубіжні дослідники (Л. Азарова, І. Голубовська, Ю. Горицька, С. Заостровська та О. Заостровський, С. Єрьоменко, М. Іваницька, I. Малиновська, С. Потапенко; А. Ашева, Е. Берн, Г. Богін, С. Воркачов, О. Залогіна, К. Іванцова, О. Кабановська, В. Карасик, Ю. Караулов, Л. Клобукова, Т. Кочеткова, М. Ляпон, О. Михалевич, М. Мозер, В. Нерознак, М. Цуциєва, Дж. Ягер та інші).

Цими загальними тенденціями вмотивовуємо актуальність запропонованої до розгляду теми, а саме: розмежування наукового (освітнього) і освітянського дискурсу.

Мета статті - окреслити межі нового дискурсу - освітянського. Об'єкт дослідження різні рівні функціонування української мови, a предмет - чітке окреслення теоретичних і практичних засад синтезу класичних підходів в освітянському дискурсі з сучасними розробками в ділянці нейролінгвістики, сугестології, нейролінгвістичного програмування i сучасних технічних засобів (телефон, комп'ютер) і мережі «Інтернет» у процесі навчання.

Завданням цієї статті є відмежування освітянського дискурсу від наукового і виокремлення характерних ознак.

Виклад основного матеріалу. Науковий дискурс у розумінні дослідників - це мовленнєво-мисленнєва діяльність, регламентована соціокультурними кодами науки як суспільної практики, іï правилами, традиціями, цінностями [Кротков, $2015: 4]$. Іноді його тлумачать як науковий текст, що $є$ результатом цілеспрямованої соціальної дії, фокус дій мовних i мовленнєвих, соціокультурних і прагматичних, когнітивних i психологічних чинників [Кицак $2011: 151]$. Науковий дискурс на тлі інших інституційних типів характеризується такими спільними ознаками, як статусно кваліфіковані учасники, локалізований хронотоп, визначена в межах певного соціального інституту мета, ритуально зафіксовані цінності, інтенційно закріплені стратегії, обмежена номенклатура жанрів, зумовлений арсенал прецедентних феноменів [Габидуллина 2009 : 34].

Зважаючи на суть наукового дискурсу в межах лінгвоперсонологічної скерованості нашого дослідження, визначаємо його як особливий тип інституційного спілкування, соиіокультурний та когнітивно-комунікативний феномен, у иентрі якого перебуває дискурсивна діяльність представників наукової громадськості, щзо забезпечує втілення їхніх інтенцій $і$ досягнення перлокутивного ефекту з метою передачі фахових знань та для інтелектуального й емоційного впливу на адресанта / адресантів.

Виокремлення ядерних i периферійних ознак наукового дискурсу оперте на запропонований В. Карасиком перелік параметрів, притаманних інституційному дискурсу як такому: це ознаки конститутивні, інституційності, типу інституційного дискурсу та нейтральні. До конститутивних ознак інституційного дискурсу він уналежнює мету, учасників комунікації, умови, стиль і жанри спілкування. Ознаками інституційності, на його думку, є рольові характеристики партнерів із комунікації, хронотоп, мовні кліше й дискурсивні формули. Ознаки інститу- 


\begin{tabular}{|c|c|}
\hline $\begin{array}{c}\text { Науковий дискурс } \\
\text { ознаки } \\
\end{array}$ & $\begin{array}{c}\text { Освітянський дискурс } \\
\text { ознаки } \\
\end{array}$ \\
\hline статусно кваліфіковані учасники & статусно некваліфіковані учасники \\
\hline локалізований хронотоп & нелокалізований хронотоп \\
\hline $\begin{array}{l}\text { визначена мета в межах певного соціального } \\
\text { інституту }\end{array}$ & визначена мета в межах певного соціального інституту \\
\hline ритуально зафіксовані цінності & $\begin{array}{l}\text { ритуально зафіксовані цінності (ці цінності відчутно } \\
\text { різняться із науковим дискурсом) }\end{array}$ \\
\hline інтенційно закріплені стратегії & $\begin{array}{l}\text { iнтенційно закріплені стратегії (ці стратегії питомо } \\
\text { різняться із класичним науковим дискурсом } \\
\text { i продиктовані форматом нових платформ освіти) }\end{array}$ \\
\hline обмежена номенклатура жанрів & $\begin{array}{l}\text { необмежена номенклатура жанрів (під впливом } \\
\text { сучасних освітніх платформ формуються нові жанри } \\
\text { чи форматуються старі) }\end{array}$ \\
\hline зумовлений арсенал прецедентних феноменів & $\begin{array}{l}\text { зумовлений арсенал прецедентних феноменів (цей } \\
\text { арсенал відчутно різниться із класичними) }\end{array}$ \\
\hline
\end{tabular}

ційного дискурсу охоплюють тип суспільного інституту, функції учасників спілкування, поведінкові стереотипи та створювані тексти.

До нейтральних ознак зараховано типові для будь-якого спілкування характеристики, особистісно-орієнтовані і транспоновані з інших дискурсів [Карасик 2000 : 11]. Нижче схарактеризуємо нейтральні дискурсивні ознаки досліджуваного типу інституційного спілкування, до яких уналежнено ті, що притаманні й іншим дискурсам. Такими є об'єктивність, логічність і лінеарність, а також обтрунтованість.

Професор I. Колегаєва стверджує, що метою кожного наукового дослідження є встановлення істини, яка існує об'єктивно, поза конкретною творчою свідомістю. 3 огляду на це таке дослідження вже на початковому етапі набуває позаособистісного, об'єктивного характеру [Колегаева $1991: 32]$.

Метою наукового дискурсу $є$ здобування й передача нових фахових знань про об'єкт та предмет дослідження, його властивості, висвітлення певної наукової проблеми, ознайомлення 3 результатами дослідницької діяльності, висловлення позиції щодо певної наукової проблеми.

Але сучасний світ і нові реалії диктують свої певні вимоги до освітнього процесу. Цифоровізація освіти та розвиток нових способів навчання, серед яких можна зазначити LMSкурси, телефонні додатки (Busuu, Doulingvo, Memrise, Drops, LinGo i подібні), авторські блоги у соціальних мережах "Facebook", "Instagram”, “TikTok” та "Youtube”, та таких бло- герів, як@shymanovski,@olexandavramenko, @unext_uamaslly.a, @zno_natali, @bo_zno, @.ukrainelowe, @mova_zno. Вони відчутно форматували традиційний формат наукового дискурсу. 3'явилися нові формати навчання: сьогодні можливо записати лекційний / урочний матеріал, скористатися автоматичними тестами, задля реклами викладачі почали викладати свої робочі матеріли і форматувати ï таким чином, щоб привернути увагу, керуючись при цьому не тільки критеріями науковості й педагогічності, але й маркетологічніими та рекламними чинники. Отже, варто говорити про набуття освітянським дискурсом відмінних питомих умов від наукового дискурсу ознак.

Для подальшого (освітній - освітянський дискурси) термінологічного розмежування доцільно зважити на тлумачення цих слів у тлумачному академічному словнику: науковий - той, що стосується науки, освітній - той, що стосується освіти, освітянський - той, що стосується освітян. Отже, під освітянським дискурсом варто розуміти лише дискурс, що стосується освітян. Його метою $є$ передача інформації, знань, необхідних для здобуття освіти; учасниками цього дискурсу є лектор, викладач, студент, типовими жанрами - лекція, дискусія, колоквіум, консультація, порада, презентація, семінарське, лабораторне та практичне заняття та нові відео у мережах, лекції і курси. У найзагальнішому вигляді мету освітянського дискурсу формулюють як розв'язання наукових проблем, що мають теоретичний чи прикладний характер. 
Якщо порівняти освітянський дискурс із науковим, то можна зазначити такі його знаки: статусно некваліфіковані учасники (у науковому дискурсі - статусно кваліфіковані учасники), нелокалізований хронотоп (у науковому дискурсі - чітко локалізований хронотоп), визначена в межах певного соціального інституту мета (спільне 3 науковим дискурсом), ритуально зафіксовані цінності (ці цінності відмінні від тих, що характеризують науковий дискурс), інтенційно закріплені стратегії (із класичним науковим дискурсом не збігаються і продиктовані форматом нових платформ освіти), необмежена номенклатура жанрів (під впливом сучасних освітніх платформ формуються нові жанри чи форматуються старі), зумовлений арсенал прецедентних феноменів (цей арсенал не такий, як у класичному дискурсі).

Висновки. Підводячи підсумки, необхідно зазначити таке: освітянський дискурс - це дискурс, який стосується безпосередньо освітян і має такі ознаки (табл. 1).
Перспективи подальших досліджень. Першою очевидною перспективою популяризації української мови через канали телебачення, 3МI, відкриті лекції, інтернет-мережею, за допомогою яких поширюється інформація про історію та розповсюдження української мови, $\epsilon$ відтворення мовної гармонії у суспільстві, вкорінення культури мови, розвиток і збереження рідної мови. Узагальнення актуальних питань освітянського дискурсу українського вченоголінгвіста дає підстави казати про пріоритет його національних цінностей, високу повагу до рідної мови як фундаментального показника національної ідентичності та наскрізну кооперативність інтерактивних виявів, що визначає концептуальними складниками його психоментальної структури націєцентричність, мовоцентричність та емпатоцентричність. Перспективи дослідження вбачаємо в подальшому розробленні засад і методологічної бази лінгвоелітології, розширенні й урізноманітненні представлення елітарних мовних особистостей.

\section{ЛІТЕРАТУРА}

1. Карасик В. И. Дискурсивная персонология. Язык, коммуникаиия и социальная среда. Воронеж : ВГУ, 2007. Вып. 7. С. 78-86.

2. Карасик В. И. О категориях дискурса. Языковая личность: социолингвистический и эмотивный аспекты. Волгоград : Перемена, 1998. С. 185-196.

3. Карасик В. И. О типах дискурса. Языковая личность: институциональный и персональный дискурс. Волгоград : Перемена, 2000. С. 5-20.

4. Карасик В. И. Языковая личность : аспекты изучения. II Международ. науч. конф. «Язык и культура». Москва, 2003. С. 362-363.

5. Карасик В. И. Языковой круг : личность, концепты, дискурс: монография. Волгоград : Перемена, 2002. $477 \mathrm{c}$.

6. Кицак Г. Характерні риси наукового дискурсу. Лінгвістичні студї Донецьк : ДонНУ, 2011. Вип. 23. С. 148-152.

7. Кротков Е. Научный дискурс. Современный дискурс-анализ. 2010. Вып. 2. Т. 1. С. 4-18.

8. Кротков Е. Научный дискурс: философско-методологический анализ. Credo new. 2014. № 3 (79). URL: http://www.intelros.ru/ readroom/credo_new/k3-2014/25369-nauchnyydiskurs-fiosofsko-metodologicheskiy-analiz.html (дата звернення: 20.03.2018).

9. Кротков Е. Философско-методологический анализ научного дискурса. Современный дискурс-анализ. 2015. Вып. 13. С. 4-16.

10. Колегаева И. М. Текст как единица научной и художественной коммуникации: монография. Одесса : Редакционно-издательский отдел областного управления по печати, 1991. 121 с.

11. Ковалевська Т. Ю. Передмова. Мова: структура, суспільство, культура. [До дня народження професора Бондаря Олександра Івановича]. Одеса : Одеський регіональний інститут державного управління Національної академії державного управління при Президентові України, 2012. С. 3-4.

12. Романченко А. П. Елітарна мовна особистість у просторі наукового дискурсу : комунікативні аспекти : монографія Одеса. 2019. 542 с.

\section{REFERENCES}

1. Karasik, V. I. (2007). Dyskursyvnaia personolohyia [Discursive personology] Language, communication and social environment (Issue 7), (pp. 78-86). Voronezh : VSU [in Russian].

2. Karasik, V. I. (1998). O katehoryiakh dyskursa [On the categories of discourse. Linguistic personality: sociolinguistic and emotional aspects]. Volgograd: Peremen, (pp. 185-196) [in Russian]. 
3. Karasik, V. I. (2000). O typakh dyskursa [On the types of discourse. Linguistic personality: institutional and personal discourse]. Volgograd: Peremen, (pp. 5-20) [in Russian].

4. Karasik, V. I. (2003). Yazykovaia lychnost: aspekty yzuchenyia [Linguistic personality: aspects of study]. II International. scientific conf. "Language and Culture". Moscow, (pp. 362-363) [in Russian].

5. Karasik, V. I. (2002). Yazykovoi kruh: lychnost, kontsepty, dyskurs: monohrafyia [Language circle: personality, concepts, discourse: monograph]. Volgograd: Peremen [in Russian].

6. Kitsak, G. (2011). Kharakterni rysy naukovoho dyskursu [Characteristic features of scientific discourse. Linguistic studies] Donetsk: DonNU,. (Issue 23), (pp. 148-152) [in Ukrainian].

7. Krotkov, E. (2010). Nauchnyi dyskurs [Scientific discourse]. Modern discourse analysis. (Issue. 2. T. 1), (pp. 4-18) [in Russian].

8. Krotkov, E. (2014). Nauchnyi dyskurs: fylosofsko-metodolohycheskyi analyz [Scientific discourse: philosophical and methodological analysis]. Credo new. № 3 (79). LIWC URL: http: // www. intelros.ru/ readroom / credo_new / k3-2014 / 25369-nauchnyydiskurs-fiosofsko-metodologicheskiy-analiz.html (дата звернення: 09.10.2021) [in Russian].

9. Krotkov, E. (2015). Fylosofsko-metodolohycheskyi analyz nauchnoho dyskursa [Philosophical and methodological analysis of scientific discourse]. Modern discourse analysis. (Issue. 13), (pp. 4-16) [in Russian].

10. Kolegaeva, I. M. (1991). Tekst kak edynytsa nauchnoi y khudozhestvennoi kommunykatsyy: monohrafyia [Text as a unit of scientific and artistic communication: a monograph]. Odessa: Editorial and publishing department of the regional press department. [in Ukrainian].

11. Kovalevskaya, T. Yu. (2012). Peredmova. Mova: struktura, suspilstvo, kultura. [Do dnia narodzhennia profesora Bondaria Oleksandra Ivanovycha]. [Preface. Language: structure, society, culture]. [To the birthday of Professor Bondar Alexander Ivanovich]. Odessa: Odessa Regional Institute of Public Administration of the National Academy of Public Administration under the President of Ukraine (pp. 3-4) [in Ukrainian].

12. Romanchenko, A. P. (2019). Elitarna movna osobystist u prostori naukovoho dyskursu: komunikatyvni aspekty: monohrafiia [Elite linguistic personality in the space of scientific discourse: communicative aspects: monograph]. Odessa. [in Ukrainian].

\section{H. M. TRUBA}

Candidate of Philological Sciences, Associate Professor, Senior Lecturer at the Department of Applied Linguistic, Odesa I. I. Mechnikov State University, Odesa, Ukraine E-mail:3182009060@ukr.net http://orcid.org/0000-0001-9944-0476

\section{THE TEACHERS' DISCOURSE: BASIC CONCEPTS AND DIFFERENTIAL FEATURES}

The relevance of the topic, namely the distinction between teachers' (educational) and educational discourse, is the popularization of educational programs and education, which led to the development of new educational traditions. The purpose of the article is to outline the boundaries of a new discourse, educational. The object of research - different levels of functioning of the Ukrainian language, and the subject - a clear outline of theoretical and practical principles of synthesis of classical approaches in educational discourse with modern developments in neurolinguistics, suggestology, neurolinguistic programming and modern hardware (phone, computer) and network "Internet" in the learning process. In contrast to the scientific discourse within the linguo-personal orientation of our study is defined as a special type of institutional communication, socio-cultural and cognitive-communicative phenomenon, which focuses on the discursive activities of the scientific community, ensuring the implementation of their intentions for intellectual and emotional influence on the addressee / addressees. There are such features of teachers' (educational) discourse in comparison with scientific as status unqualified participants (in scientific discourse - $n$ status qualified participants), non-localized chronotope (in scientific discourse - clearly localized chronotope), defined within a certain social institution goal (joint with scientific) ritually fixed values (these values differ significantly from scientific discourse), intentionally fixed strategies (these strategies differ from classical scientific discourse and dictated by the format of new educational platforms), unlimited range of genres (under the influence of modern educational platforms new genres or forms are formed). due to the arsenal of precedent phenomena (this arsenal is significantly different from the classical ones).

Key words: discourse, educational discourse, teachers' discourse. 